\title{
Not an alternative medicine at St Marylebone Parish Church
}

\author{
C K HAMEL-COOKE, D H P COPE
}

The origin of the idea to combine a doctor's surgery with the pastoral care of a priest for his people began with a proposal, made by $\mathrm{CKH}-\mathrm{C}$ to the general practitioners who are members of the Bedford field group of the Institute of Religion and Medicine. The parish priest of a large residential parish is called on to take a funeral, perhaps once a week. Contact is made by the funeral director, who telephones to suggest a date

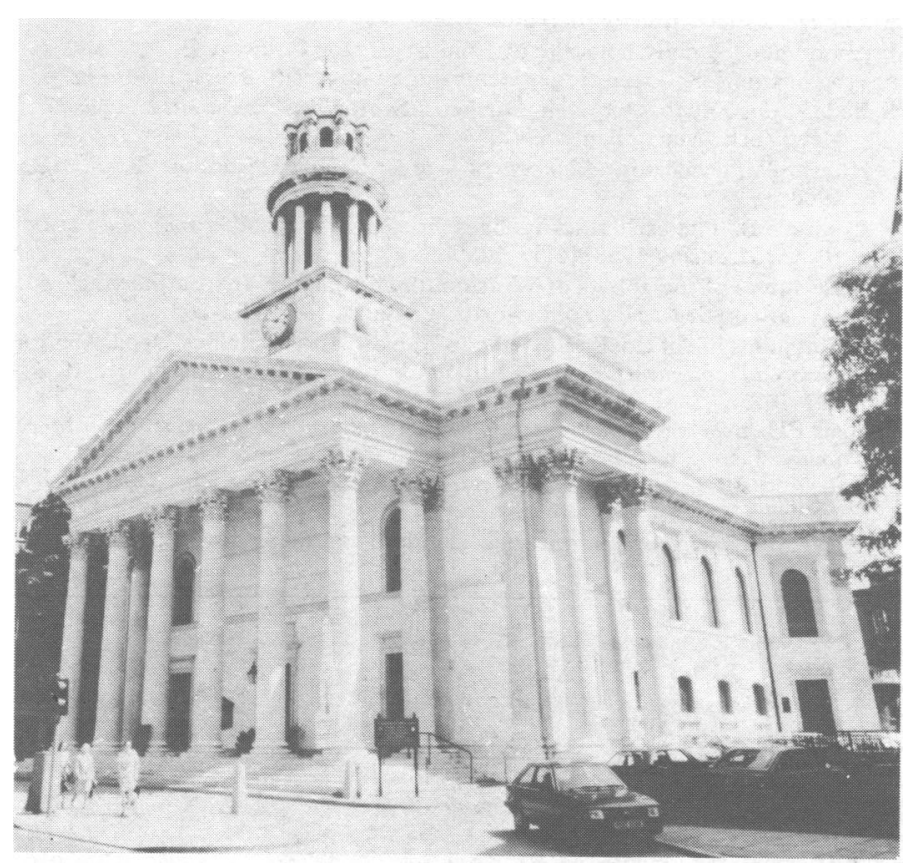

FIG 1-St Marylebone Parish Church.

and time. The vicar does not know that $\mathrm{Mr} \mathrm{X}$ has existed until he learns that he has died. He calls to visit the widow and feels at a considerable disadvantage because he had not been to see the deceased while he was ill. Why did the general practitioner not let him know ? He was not asked to do so-religion never came into the conversation. Whose parish does he happen to be in? Does the doctor have confidence in that particular priest or minister? So the suggestion: why not appoint chaplains to general practices as they are appointed by the Department of Health and Social Security to every National Health Service hospital in the country? Still a good idea-but it has nowhere yet been tried. In seeking to establish a centre for Christian healing and counselling at St Marylebone parish church, the idea was to implement that proposal in reverse-not a chaplain to a practice, but a practice attached to the church (fig 1).

St Marylebone Parish Church, Marylebone Road, London NW C K HAMEL-COOKE, MA, DPS, rector

D H P COPE, MB, FFARCS, honorary treasurer

\section{The premises}

Beneath the enormous church and extending beyond is the crypt, which was built as a burial chamber. The gentry of St Marylebone were buried there between 1817 when the church was built, and 1850 , by which time it was full (fig 2 ). They were then "bricked in" in their lead lined coffins, and left. Indescribable was the scene when we came to move them. Coffins had been crammed into every available space, one on top of another. A hundred and twenty years later, they had nearly all collapsed and the scene of dereliction was grim indeed. Firms of builders and funeral directors worked together to clear the horrid sight. They did so in a wonderful spirit of reverence and care and left us with an empty and movingly beautiful undercroft, which was shortly afterwards dedicated for its new use in the care of the living. The bodies now lie in a corner of the lovely forest at Brookwood cemetery.

\section{A normal NHS practice}

St Marylebone is the parish church of Harley Street. Eight hospitals, two NHS and six private, are served by its clergy as chaplains. Three great teaching hospitals are just over its borders. More medicine is practised in these few acres than in any equivalent area in the world, but it is difficult to enrol as an NHS patient in a local practice. The need for the surgery exists quite apart from the project that we envisage. The Acheson committee, reporting in 1981, found serious de-

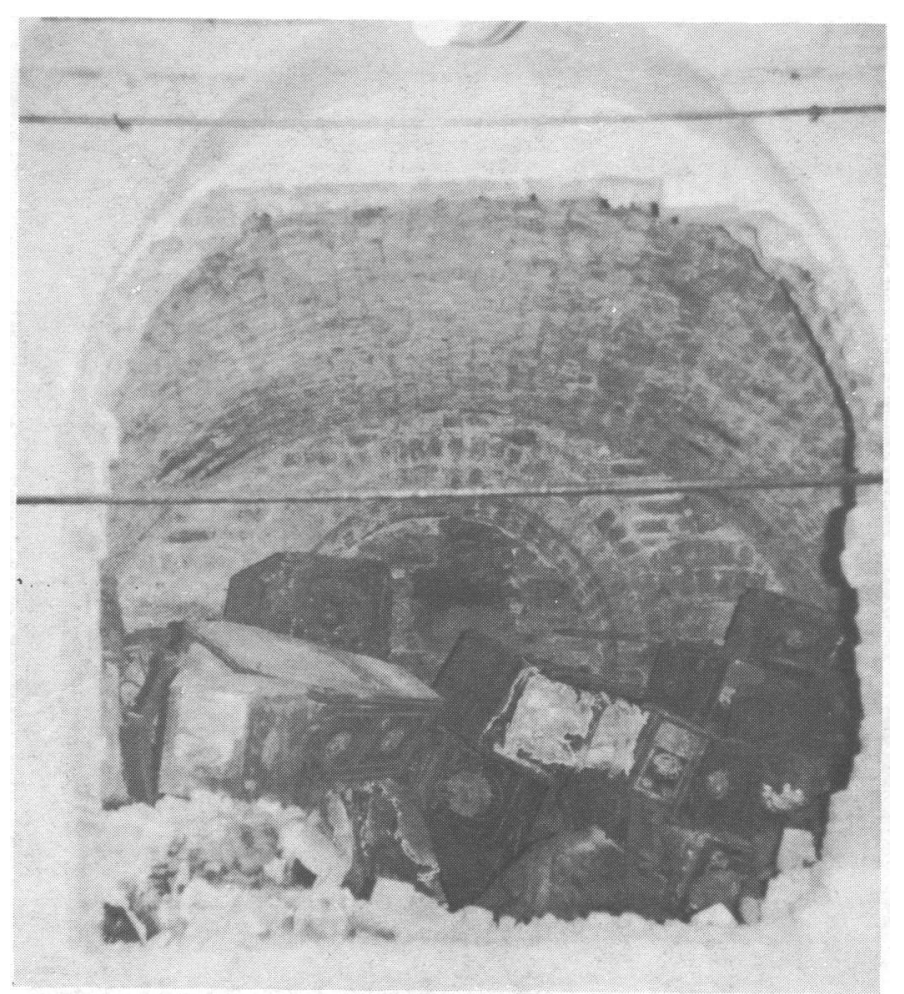

FIG 2-Coffins in the crypt. 


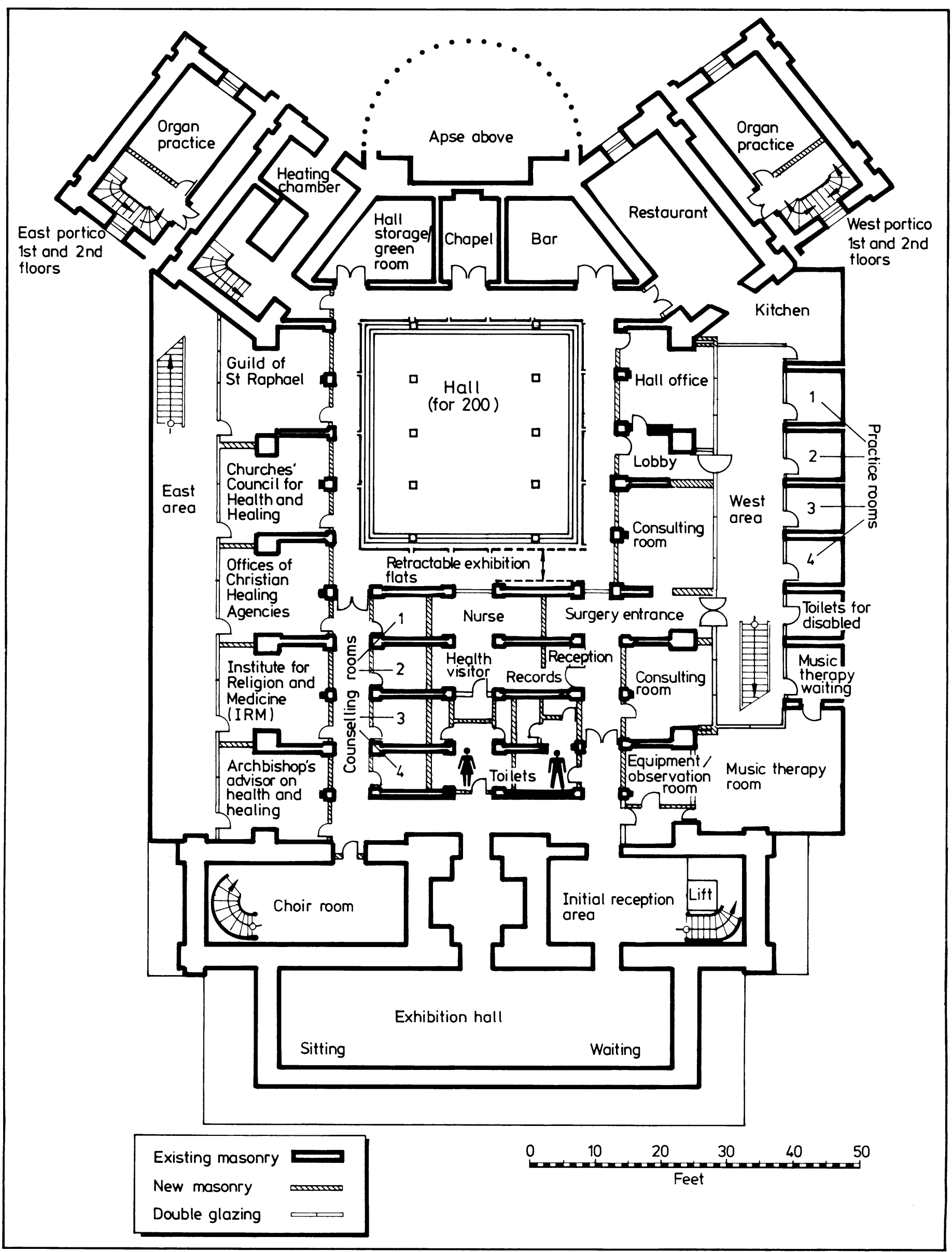

FIG 3-Proposed development map of the crypt. 
ficiencies in the provision of medical care in central London and criticised particularly the inadequate facilities and staffing of most general practices. ${ }^{1} \mathrm{~A}$ known and considerable need will be met-and it must be stated that it will be a normal NHS practice functioning like any other and serving all manner of people, of every colour, class, and creed. It is hoped that the doctor will be accepted as a partner in one of the local NHS practices but that he, his nurse, and health visitor will all be committed Christians, ready and eager to cooperate with the priest and his staff, who will be seeking to help, counsel, or pray for any who may wish to receive this kind of ministry. Many will come to the doctor only; many will come to the priest; but those who wish to be referred by either to the other will know that that option is always open (fig 3 ).

\section{What is the churches' healing ministry?}

It is certainly not an alternative medicine. When Sir Douglas Black was approached and asked to sponsor the venture, he expressed himself ready to do so once he had established that point. The other sponsors are the Archbishop of Canterbury Dr Robert Runcie and the Lord Chancellor Lord Hailsham of St Marylebone. It is important to make this clear in the context of so much recent controversy. We believe that the failure of the churches to fulfil their commission to "heal the sick" over a long period has resulted in the upsurge of many strange and often way out claims by all sorts of people and bodies without qualification and without commission, not on the fringe but far from the fringe of either medical or religious orthodoxy. It is in part to reclaim for the churches their rightful place in the scheme of things that this project is being set up.

The value of prayer, the way it "works," the manner of its testing-these issues will go on being debated. Meanwhile, many people are seeking someone to pray for them and, if possible, with them. The sacraments-Holy Communion, Anointing, and Laying on of hands-are enacted prayers, outward and visible signs. The principle behind them is closely related to the psychosomatic principle understood by medicine. As the body expresses a mental ailment, or a spiritual disease, so through the body the medicine of the spirit is relayed. Who could contest the value of the touch of a loving or caring person to one in distress of heart or mind? There are many whose only problem is the want of someone to talk to. The centre will provide "befrienders" (the first and simplest level of counselling), then men and women more skilled in case work, and ultimately, reference to the psychiatrist or psychotherapist. In addition, it will provide a caring community, a place where people can come to find and make friends; the church is an "extended" family, and membership of it gives to all who want it a whole host of new relationships-the absence of which again, is the cause of so many people's distress. Is this not what the Prince of Wales reiterated in his address at the BMA dinner in December $1982,{ }^{2}$ when he stated, "I would suggest that the whole imposing edifice of modern medicine, for all its breathtaking successes is, like the celebrated Tower of Pisa, slightly off balance." He had also said: "By concentrating on smaller and smaller fragments of the body, modern medicine perhaps loses sight of the patient as a whole human being, and by reducing health to mechanical functioning it is no longer able to deal with the phenomenon of healing."

\section{Healing agencies}

The Churches' Council for Health and Healing, which "overarches" the many Christian agencies and provides a link between them and the royal colleges, already has its office at St Marylebone. The Churches' Council for Drugs and Alcohol proposes to move in also. The advisor to the Archbishops of Canterbury and York, Bishop Morris Maddocks, has his London base in the centre. The coordination of agencies (and the pooling of their resources) makes for greater efficiency and considerable saving. Music therapy is also to find a place in the centre. Healing services are already being held at St Marylebone Parish Church on the first Sunday of each month at $630 \mathrm{pm}$.

\section{Teaching}

St Marylebone Parish Church is within walking distance of three undergraduate teaching hospitals. It is hoped to establish a link between one or more of these hospitals so that interested students could attend the centre as part of their general practice or psychiatric appointments. Longer attendance could be arranged as a subject for an elective period. They would learn how Christian counselling can complement medical care, especially where the latter has failed to cure severe physical or emotional pain completely. The spiritual care of preterminal cases, the incurable, and the bereaved is a subject of which all doctors should be aware and will be most appropriately taught in the healing centre.

Social workers and community nurses may also wish to benefit from observing the work that is being planned.

\section{Other interests}

In addition to social facilities-hall, bar, restaurant-there is already a bookshop and it is hoped that there will be a library. The hall will be available to outside bodies for lectures and exhibitions as well as being a teaching centre. Teaching and training will be an integral part of the ministry. The need to train the people we shall need to help will be a continuing part of our work.

St Marylebone is a parish church with a famous musical tradition. Under the new principal of the Royal Academy of Music, the links between the institutions, which face each other across the Marylebone Road, are being strengthened. The new organ will be at the service of the academy, who propose a new course in training church musicians, in which our two teams of staff would cooperate.

Preparation for the development of the crypt for its new role has cost many thousands of pounds. The whole conversion will cost $£ 500000$, and we have raised so far $£ 250000$ specifically towards this part of the church's $£ 900000$ appeal. Financial support for what we are doing is paramount for its achievement, and an appeal director, the Reverend Richard McLaren, is employed full time to bring this about. Awareness of the St Marylebone project will, we hope, attract much support from members of the medical profession. Equally important, the appeal should be brought to the notice of any of their patients who would be sympathetic to the ideals. From the support that we have been receiving, it does seem, though it has yet to happen, that before very long, this vision will become a reality and a new partnership of religion and medicine, a new concept in cooperation between priest and doctor will have been established. We hope that it may be emulated in many other places, not as an alternative to medicine but in cooperation with medicine, to provide care and healing in those areas which are not susceptible to scientific medicine.

\section{References}

${ }^{1}$ London Health Planning Consortium Study Group. Primary health care in inner London, report. London: HMSO, 1981. (Acheson report.)

${ }^{2}$ HRH The Prince of Wales. Drugs: the patient has had enough. Presidential address at BMA Council dinner, 14 December 1982. The Times 1982;December 16:12 (col 2-4). 